Review

\title{
Implication of COVID-19 on Erythrocytes Functionality: Red Blood Cell Biochemical Implications and Morpho-Functional Aspects
}

\author{
Annamaria Russo ${ }^{1}$, Ester Tellone ${ }^{2, *} \mathbb{C}$, Davide Barreca ${ }^{2, *} \mathbb{D}$, Silvana Ficarra ${ }^{2}$ and Giuseppina Laganà ${ }^{2}$ \\ 1 Istituto Comprensivo Primo, 98057 Milazzo, Italy; annamaria.russo81@posta.istruzione.it \\ 2 Department of Chemical, Biological, Pharmaceutical and Environmental Sciences, University of Messina, \\ Viale Ferdinando Stagno d'Alcontres 31, 98166 Messina, Italy; silvana.ficarra@unime.it (S.F.); \\ giuseppina.lagana@unime.it (G.L.) \\ * Correspondence: ester.tellone@unime.it (E.T.); davide.barreca@unime.it (D.B.)
}

Citation: Russo, A.; Tellone, E.; Barreca, D.; Ficarra, S.; Laganà, G. Implication of COVID-19 on Erythrocytes Functionality: Red Blood Cell Biochemical Implications and Morpho-Functional Aspects. Int. J. Mol. Sci. 2022, 23, 2171. https:// doi.org/10.3390/ijms23042171

Academic Editor: Francesco Misiti

Received: 27 January 2022

Accepted: 14 February 2022

Published: 16 February 2022

Publisher's Note: MDPI stays neutral with regard to jurisdictional claims in published maps and institutional affiliations.

Copyright: (C) 2022 by the authors. Licensee MDPI, Basel, Switzerland. This article is an open access article distributed under the terms and conditions of the Creative Commons Attribution (CC BY) license (https:// creativecommons.org/licenses/by/ $4.0 /)$.

\begin{abstract}
Several diseases (such as diabetes, cancer, and neurodegenerative disorders) affect the morpho-functional aspects of red blood cells, sometimes altering their normal metabolism. In this review, the hematological changes are evaluated, with particular focus on the morphology and metabolic aspects of erythrocytes. Changes in the functionality of such cells may, in fact, help provide important information about disease severity and progression. The viral infection causes significant damage to the blood cells that are altered in size, rigidity, and distribution width. Lower levels of hemoglobin and anemia have been reported in several studies, and an alteration in the concentration of antioxidant enzymes has been shown to promote a dangerous state of oxidative stress in red blood cells. Patients with severe COVID-19 showed an increase in hematological changes, indicating a progressive worsening as COVID-19 severity progressed. Therefore, monitored hematological alterations in patients with COVID-19 may play an important role in the management of the disease and prevent the risk of a severe course of the disease. Finally, monitored changes in erythrocytes and blood, in general, may be one of the causes of the condition known as Long COVID.
\end{abstract}

Keywords: SARS-CoV-2; red blood cells; COVID-19; hemoglobin; infections; hematology

\section{Introduction}

The exchange of gases between the tissues and lungs and the maintenance of the acid-base balance represents the main goal played by the circulatory system. Red blood cells (RBCs) are the major cellular components of the blood, and, for this reason, their role is essential not only to ensure the right supply of oxygen to the tissues and the concomitant excretion of carbonic dioxide $\left(\mathrm{CO}_{2}\right)$ but also to define the biophysical consistency of the blood and the efficiency of the entire bloodstream. To best perform their oxygen transport function, mature RBCs are deprived of the nucleus and organelles to make way for hemoglobin $(\mathrm{Hb})$, the main protein responsible for oxygen transport. $\mathrm{Hb}$ is a tetrameric molecule floating between two conformational states, $\mathrm{T}$ at low oxygen affinity and $\mathrm{R}$ high oxygen affinity [1]. The oxygen binding and release by $\mathrm{Hb}$ are strictly modulated by a complex of homo- and heterotrophic factors, including the $\mathrm{pH}$ of blood; at low oxygen pressure, the $\mathrm{CO}_{2}$ dissociation promotes blood acidification with consequent $\mathrm{T}$ state stabilization and oxygen release from $\mathrm{Hb}$. The oxygen release is also effectively facilitated by $\mathrm{CO}_{2}$ and 2,3-bisphosphoglyceric acid, both contributing directly to the main and most studied activity of RBCs: the oxygen transport from the lungs to tissues and carbon dioxide from the tissues to the lungs, where it will be exhaled.

In addition to their canonical role as gases and nutrients transporters, being cells in close contact with oxygen, RBCs possess a very efficient antioxidant system that preserves their integrity. They are also important modulators of nitric oxide (NO) metabolism and 
participate in the control of blood rheology via their concentration (hematocrit), which critically and specifically defines the viscosity of the blood.

Pathological alterations of RBCs disturbing their cellular function and/or deformability have been associated with several diseases, such as diabetes, sickle cell anemia, malaria, and some neurodegenerative diseases [2-8]. In this article, we will specifically evaluate some functional and structural alterations of RBCs related to COVID-19 disease. In fact, despite the development of vaccines, the worldwide data show that the pandemic is not yet under control and further studies need to better understand the biology of viral infection. In addition, the persistent post-infection symptomatology reported by several healed COVID-19 patients requires a more accurate and extensive study focused on the hematological changes related to SARS-CoV-2 infection. The work carried out in this review aims to highlight the combination of hematological and erythrocyte dysregulation mechanisms that favor the evolution of SARS-CoV-2 infection in order to inspire the scientific community and enhance therapeutic approaches against COVID-19.

\subsection{Coronavirus Disease}

COVID-19 is an infectious disease. Its acronym COronaVIrus Disease (19 indicates the year during which the virus was first identified) derives from its viral origin. In fact, COVID-19 is caused by a virus called SARS-CoV-2, belonging to the Coronaviridae family, a group of enveloped positive-sense single-stranded RNA viruses that cause gastrointestinal and respiratory infections $[9,10]$. The new Coronavirus, responsible for the current pandemic, emerged in Wuhan, China, and is also formally called SARS-CoV-2 (Severe Acute Respiratory Syndrome Coronavirus 2) to distinguish it from SARS-CoV and MERS-CoV (Middle East Respiratory Syndrome Coronavirus) [11]. Coronaviruses, in general, are known to infect the bronchial epithelium cells and the superficial respiratory tract; they can be the cause of severe pathologies and serious lung damage, leading, in some cases, to death from air deficiency. The new Coronavirus, responsible for COVID-19, causes the most acute respiratory pathology with multiorgan complications and distinctive symptoms, such as cough, fever, headache, astheny, difficulty breathing, and gastrointestinal disorders [12]. In addition, peculiar transient COVID-19 symptoms are anosmia (lack of smell) and ageusia (lack of taste).

\subsection{Coronavirus}

The Coronavirus name derives from the characteristic crown shape conferred to the virus by the proteins on its outer shell, known as spikes (thorns). Spike proteins favor the virus infection to human cells as they have a sort of molecular hook (RBD = Receptor Binding Domain) with which the viral spike proteins bind to Angiotensin-converting enzyme 2 (ACE2) receptors [13]. This last is an important regulator of blood pressure, and it is expressed in the lung and on the epithelial cells of the small intestine. The ACE2 expression in the small intestine could explain the potential fecal-oral transmission of the virus, in addition to respiratory transmission. RBD-ACE2 binding is essential to initiate infection but, the virus also exploits the sialic acid receptor present in the tissues of the upper respiratory tract. From a structural point of view, the corona of the virus consists of four proteins; from the outside: spike, envelope, membrane, and nucleocapsid, this last surrounding the RNA [14]. The viral complex incorporation takes place by the conformational change of the spike protein induced by the binding between RBD and the ACE2 receptor of the host cell: the conformational change of the spike protein approaches the viral membrane to the plasma membrane of the host cell, up to the interaction, the fusion between membranes and, finally, the incorporation of the infecting virus. Once the viral genome is inside the host cell, the virus begins its replication, and the infection process can be considered complete. SARS-CoV-2 "appropriates" the host's ribosomes and exploits them to translate its genome and synthesizes proteins necessary for viral replication and assembly of new virions. With the transcription and replication of the viral genome, SARS-CoV-2 begins to spread in the host, starting the real infectious disease [15]. 


\subsection{Clinical Aspects of COVID-19 Infection}

The infection can start asymptomatic, or it manifests with common influenza symptoms (fever, cough), gastrointestinal disorders, loss of taste and smell, or conjunctivitis. Some COVID-19 patients may develop dyspnea and severe respiratory failure due to the development of interstitial pneumonia with high fever, myocardial damage, and risk of death [15]. The respiratory failure complication derives from the virus' entry into the pulmonary alveoli; the human immune system counteracts this invasion, activating a strong inflammatory response with rapid and important release of interleukin- 6 and other pro-inflammatory cytokines, such as chemokines, tumor necrosis factor- $\alpha$, and interleukina$1 \beta$ [16]. The picture of "cytokine storm" is configured, which can cause a serious insufficiency of several organs and lead to the death of the patient [17]. Therefore, "acute respiratory distress syndrome" characterized by diffuse alveolar damage, shock, and acute renal failure is the most frequent complication of viral infection. In addition, some COVID19 patients experience alterations in blood clotting resulting in severe thromboembolic events [18].

\section{COVID-19 and RBCs Metabolism}

Many Coronavirus patients have acute lung involvement, accompanied by hypoxia and dyspnea as alarming symptoms. Others experience a seemingly well state, in which the lungs do not appear severely damaged despite insufficient blood oxygenation (silent hypoxia) [19]. These conditions have led several research groups to suppose a direct involvement of erythrocytes in Coronavirus infections [20-22]. Cosic et al., in 2020, through studies performed with the Resonant Recognition Model (RRM), proposed RBCs as an alternative point of access to the SARS-CoV-2 virus, which, by entering through the alveoli membrane in the lung, reaches the bloodstream [21]. In the blood, SARS-CoV-2 infects RBCs through the binding between S1 Spike protein and Band-3 protein on the erythrocyte membrane [20]. Moreover, Band-3 has already been indicated as a binding receptor for protozoan parasites, such as Plasmodium falciparum [23]. The link between Band-3 and the virus does not support viral replication but can affect different characteristics of the RBC, also linked to its functionality (as well as the release of oxygen). In this context, studies on RBCs from COVID-19 patients have highlighted significant metabolic alterations related to an increase in the glycolytic pathway to the detriment of the pentose phosphate pathway, highlighted by a characteristic increase in glucose consumption accompanied by an accumulation of intermediates of the glycolysis and higher levels of phosphofructokinase (PFK), the rate-limiting enzyme of glycolysis [24]. The metabolic shift towards ATP production in the glycolytic pathway clearly, also influences other metabolic pathways, such as the pentose phosphate pathway (PPP). In these conditions, the non-oxidative phase of PPP is increased, in which glycolysis intermediates are converted into the ribose-5-phosphate required for the synthesis of the nucleic acids, which is necessary for the virus replication $[25,26]$. In addition, high levels of oxidized glutathione and a significant decrease in enzymes forming part of the cellular defense line against oxidative stress were found, including superoxide dismutase 1 (SOD1), glucose-6-phosphate dehydrogenase, and peroxiredoxin [27-29]. RBCs from COVID-19 could, therefore, be more exposed to the attack of reactive oxygen species (ROS), resulting in induced cellular lysis and inability to carry oxygen. Recalling the important role played by the cytoplasmic domain of Band-3 as a regulator of erythrocyte metabolism in response to the different states of $\mathrm{Hb}$ oxygenation, it could be thought that the SARS-Band-3 bond alters the binding capacity of the cytoplasmic domain of Band-3 to glycolytic enzymes and deoxygenated $\mathrm{Hb}$, causing the recorded metabolic irregularities [30,31]. Last but not least, it has been shown that Band-3 protein is associated with RBC membrane in a macro-complex that coordinates the shape of the cell (by the cytoskeletal proteins bound), carbon dioxide uptake (by the action of Carbonic anhydrase II bound to the C-terminal domain of Band-3), and the oxygen release from $\mathrm{Hb}$ (by the Bhor effect and by the direct binding between the cytoplasmic domain of Band-3 and deoxygenated 
$\mathrm{Hb}$ ) [32]. In this context the attack of S1 Spike protein to Band-3 protein on the erythrocyte membrane [20] may affect the release of oxygen to metabolically active tissues.

\section{Hemoglobin and SARS-CoV-2}

Coronavirus, similar to other viruses, is able to interact with protoporphyrin IX through the spike protein. The interaction takes place between the beta chains $\mathrm{of} \mathrm{Hb}$, ORF 8 , and the surface glycoproteins of the virus $[33,34]$. Liu et al. highlighted a number of viral proteins (orf1ab, ORF3a, ORF7a, ORF8a, and ORF10) as potential ligands to the 1-beta chains of hemoglobin [33]. This binding causes the $\mathrm{Hb}$ denaturation and the inhibition of viral replication by blocking (as also seen for other viruses) the SARS-CoV-2-cell fusion mediated by the spike protein $[33,35]$. Hb alteration caused by the viral proteins, decreasing the percentage of fully functional $\mathrm{Hb}$ in oxygen transport, could contribute to the development of hypoxia and multi-faceted syndrome, one of the main signs of COVID19. The involvement of $\mathrm{Hb}$ beta chains in the evolution of COVID-19 finds an objective confirmation in some studies on the potential use of umbilical fetal blood transfusion on COVID-19 patients [36]. Increasing HbF in critically ill patients could help control disease progression, minimize morbidity, and increase survival rates [37]. Furthermore, the effect of SARS-CoV-2 on $\mathrm{Hb}$ has led to an assessment of COVID-19 as a potentially acquired acute porphyria [38]. Juan et al. reported an abnormal accumulation in the serum porphyrin profile of COVID-19 patients of the by-products uroporphyrin I, coproporphyrin I, and the metabolite coproporphyrin III, determined by high-performance liquid chromatography [39]. The interaction between SARS-CoV-2 and $\mathrm{Hb}$ would take place on two fronts: at the erythrocyte level, where the virus is introduced at the intracellular level through the link between spike and Band-3 protein, and at the level of the bone marrow, where the virus interacts with nascent erythroblasts through CD147 and CD26 [40,41]. The difference is that, at the erythrocyte level, the virus enters the red blood cell and interacts with the $\mathrm{Hb}$ molecule, but its replication is prevented by the absence of a nucleus while, in erythroblasts, the presence of nuclear material would facilitate viral replication and, in this case, the normal recycling of red blood cells from the spleen to the bloodstream would be inhibited, causing anemia [42]. It is important to note that high levels of glycosylated $\mathrm{Hb}$ increase CD147 expression, with an increased risk of further complications [43]. Lower $\mathrm{Hb}$ levels have been reported in several studies conducted in patients with severe COVID-19 disease, although there is no experimental evidence to date to support an alteration of the oxygen dissociation curve [44,44-51]. The decrease in $\mathrm{Hb}$ level might be a predictor of worsening pneumonia in COVID-19 patients, associated with the need for treatment with mechanical ventilation.

As the disease worsens, other hematological markers associated with hemoglobin become altered, such as bilirubin and ferritin, which progressively increase [52,53]. Several researchers show elevated methemoglobin $(\mathrm{MetHb})$ and carboxyhemoglobin $(\mathrm{COHb})$ concentrations in severely ill patients' blood and suggest these former as potential markers of disease severity [54-56]. In addition to the obvious effect of oxidizing drugs, the increase in MetHb formation may derive from a physiological reaction due to the increase in nitric oxide (NO) caused by acute anemia as part of the physiological reaction to the disease [44,57-60]. In particular, in hospitalized COVID-19 cases, there has been an increase in cases of anemia equal to about $60-70 \%$. The release of NO is important for vasodilation and to prevent tissue hypoxia, but, at the same time, the NO release causes the oxidation of $\mathrm{Hb}$ in MetHb [55-57,61,62]. The increased level of $\mathrm{CO}-\mathrm{Hb}$ could instead be related to the normal accumulation in the serum of porphyrin recorded in COVID-19 patients and to the progressive increase in bilirubin potentially linked to hemolytic anemia $[38,39,52,53,56]$. To this picture is added the breathing difficulty typical of COVID-19 that leads to a deficient $\mathrm{CO}$ elimination and potential formation of $\mathrm{COHb}$. 


\section{Anemia and Iron Dysmetabolism in COVID-19}

Anemia could be linked to iron homeostasis dysmetabolism found in subjects who suffered from severe or critical COVID-19 [63]. In detail, Sonnweber et al. highlighted persistent hyperferritinemia and alterations of iron homeostasis in non-resolving lung pathologies and poor patients' performance [64]. Lanser et al. found the decline in Hb levels was more pronounced when accompanied by hyperferritinemia in hospitalized patients; transferrin levels decreased within the first week in all patients [63]. Many researches highlight low levels of $\mathrm{Hb}$ and high levels of ferritin in non-surviving patients $[52,65,66]$.

Viruses generally increase iron deposits to promote their spread to host cells, and the immune system tends to control the overload of iron through transferrin saturation [67]. In COVID-19 patients, the virus invasion causes immune activation and the release of inflammatory cytokines such as interleukin 6 , interleukin 1 beta, and tumor necrosis factor alpha [64]. Cytokines directly affect iron metabolism, triggering the production of hepcidin, the main hormone responsible for iron homeostasis, whose synthesis is increased by inflammatory cytokines and in cases of iron overload [68]. The release of hepcidin should instead be physiologically decreased in cases of anemia and hypoxia [69]. Ehsani also found a similarity (a conservative motif rich in cysteine) between the cytosolic subunit of the viral spike protein and hepcidin; SARS-CoV-2 would seem to mimic the hepcidin action [70]. Hepcidin binding to ferroportin limits the iron availability, blocking its export from cells; during COVID-19, there is, in fact, an iron overload in cells and tissues and a concomitantly reduced level of serum iron $[65,69]$. The reduced availability of serum iron results in a low transferrin saturation ratio that affects the $\mathrm{Hb}$ synthesis and erythropoiesis (RBCs production), leading to anemia of inflammation [69,71]. This decreased circulation of RBCs perpetuates hypoxemia and prevents tissue oxygenation, which is already difficult in patients with acute COVID-19 respiratory syndrome [72]. In fact, alterations in iron metabolism are associated with hypoxemia in COVID-19 patients [45,73].

\section{Hemolysis and Oxidative Stress in COVID-19}

Additional harmful processes that can occur in COVID-19 include a general increase in oxidative stress. During viral infection, neutrophils rapidly move towards the target tissues, where they release ROS in an oxidative burst necessary for eradicating phagocytosed viruses [74]. The increase in ROS favors a local inflammatory response that, if not well controlled, can cause oxidative stress phenomena that, in turn, perpetuate the activation of neutrophils, triggering a very dangerous chain reaction. Violi et al. showed that NADH oxidase2 (NOX2) is overexpressed in hospitalized COVID-19 patients [75]. The activation of NOX is one of the major factors contributing to the formation of ROS and the consequent increase in oxidative stress, inflammatory response, and increased severity of COVID-19 [76]. Lungs are the organs mainly involved in COVID-19, where the virus also causes edema, inflammation, and a decrease in oxygenation exacerbated by oxidative stress. Oxidative stress also plays a significant role in damaging the RBCs that can be impaired by becoming dysfunctional. High ROS level causes damage mainly to the erythrocyte membrane where polyunsaturated fatty acids are oxidized, leading to profound changes in the distribution of membrane lipids. These alterations affect the oxygen and carbon dioxide exchange and the deformation capacity of RBCs favoring thrombotic events observed in critically ill patients with COVID-19 [77]. In addition, the free heme, resulting from hemolysis present in the bloodstream of COVID-19 patients associated with hyperferritinemia, contributes to endothelial damage and the remodeling of pulmonary vessels [78]. The attack of SARS-CoV-2 proteins facilitates the removal of iron from the heme prosthetic group, leading to the loss of functional hemoglobin and release of free iron ions that, on the one hand, contribute to the increase in ferritin and, on the other, inexorably feed the reactions of Fenton and Haber-Weiss and oxidative stress [49,79]. Such oxidative imbalance causes mitochondrial dysfunction, further perpetuating the inflammatory state and hyperstimulating the release of cytokines; the process may culminate with ferroptosis associated with multiorgan oxidative stress in later stages of the disease $[52,80]$. Numerous data 
confirm the development of oxidative stress in viral infections [81,82]. There is evidence of a link between decreased expression of the antioxidant enzyme superoxide dismutase 3 (SOD3) in the lungs of elderly patients with COVID-19 and disease severity [83]. In addition, a low level of glutathione (GSH) and downregulation of glutathione peroxidase (GPX4) gene expression in SARS-CoV-2 infection was found [52,84-87]. In detail, in the RBCs from COVID-19 patients, Thomas et al. identified a high level of the end product of the PPP that suggests a high degree of oxidative stress also evidenced by an increase in oxidized glutathione (GSSG) [24]. To this oxidative picture is added a decrease in the most significant enzymes in the cells antioxidant response, a reduced level of peroxiredoxins (PRDX), superoxide dismutase 1 (SOD1), and glucose-6-phosphate dehydrogenase (G6PD) is registered. All these results unequivocally underline in RBCs from COVID-19 patients an increase in ROS level that may be linked to the increased aggregation and abnormal morpho-physiology observed by Renaux et al. [88]. In fact, ROS react with membrane lipids and proteins, producing lipid peroxidation and modified membrane proteins, resulting in phosphatidylserine exposure on the RBC surface. This membrane rearrangement involves an imbalance in cation homeostasis and a concomitant decrease in deformability [89]. When the endothelium is damaged by oxidative stress, RBCs may adhere to the injured matrix, contributing to thrombin generation predisposing the patient to thrombosis [90]. These alterations can contribute to thromboembolic complications and coagulopathies characteristic of some critically ill COVID-19 patients.

\section{Intra and Extra-Erythrocytic NO Levels in COVID-19 Patients}

Nitric oxide $(\mathrm{NO})$ is a free radical gas that transmits a regulatory signal produced by the endothelium whose main biological activity is to induce relaxation of the aortic vascular walls. It also plays a role as a neurotransmitter and a defense in inflammatory processes. It is produced by an enzymatic reaction catalyzed by nitric oxide synthase (NOS), present in the body under three different isoforms: neuronal (nNOS), inducible (iNOS), and endothelial (eNOS) [91].

eNOS is mostly expressed in endothelial cells with an important role in blood pressure regulation. The NO's small size and lack of charge facilitate its entry through the RBC membrane, where it is rapidly inactivated by oxyhemoglobin via conversion to MetHb and nitrate [92]. Under low oxygen saturation intra-erythrocyte, NO can also react with deoxyhemoglobin generating nitrosyl $\mathrm{Hb}$. NO levels are significantly reduced in COVID-19 patients: this is likely related to vascular dysfunction and inflammation $[87,88]$. Although SARS-CoV-2, mainly infects the cells of the bronchial epithelium and pulmonary, residual viral particles have also been found in endothelial cells, leading to apoptosis and endothelial decrease in NO $[78,93]$. However, in the RBCs of COVID-19 patients, the increased levels of NO could be related to the silent hypoxia highlighted in some cases of severe disease $[60,94]$. In this context, the high levels of intraerythrocytic NO would contribute to inhibiting the amount of oxygen released at the tissue level $[95,96]$. Reduced serum NO levels could be caused by hemolysis of RBCs, following viral infection and subsequent $\mathrm{Hb}$ release. In this case, $\mathrm{Hb}$ and free heme would rapidly bind to $\mathrm{NO}$, generating MetHb and nitrates and contributing to hypertension and vasoconstriction, elements both found in patients with severe COVID-19. NO inhibits blood clotting and excessive platelet activation, so a decrease in endothelial NO production could be related to potential thrombotic events and coagulation disorders in COVID-19 patients, characterized by a significant increase in D-dimer and risk of disseminated intravascular coagulation [97,98]. The hypothesis of a role of NO in the etiology of COVID-19 is accredited by the high risk of incurring severe COVID-19 disease for those patients suffering from diabetes, hypertension, and other cardiovascular diseases [99]. These pathologies are, in fact, often associated with decreased NO levels or decreased NO availability [100]. 


\section{COVID-19 and Long-Term Changes}

Several studies show that $50-70 \%$ of patients after 2 to 6 months still have a variety of symptoms due to SARS-CoV-2 infection [101,102]. This condition, known as "Long COVID", is characterized by a general state of malaise; recovered patients often experienced headaches, concentration disorders, weakness, muscle fatigue, and shortness of breath $[103,104]$. In this context, Pasini et al. showed that, two months after the acute phase of the COVID-19 infection, some patients continued to have an altered hematological status [104]. In detail, there are very high serum levels of ferritin and D-dimer, accompanied by significantly low levels of $\mathrm{Hb}$ and albumin and a high degree of erythrocyte sedimentation. Kubancova et al. found significant phenotypic changes in RBCs from COVID-19 recovered patients. RBCs are less deformable, smaller, and more heterogeneous in size and deformation [105]. These changes in physical properties could be related to the alterations in the structural proteins and RBC membrane highlighted by Thomas et al. [24]. The persistence of RBCs, less deformable in recovered patients, could explain the symptomatology detected in Long COVID, especially considering that the RBC's life average is estimated at 120 days [106]. This hypothesis is supported by the results of Kubancova et al. that identify phenotypic changes in blood cells even several months after SARS-CoV-2 infection [105].

\section{Erythrocyte Morpho-Functional Changes in COVID-19}

Considering the exponential progression of the SARS-CoV-2 pandemic, it is of great importance to take accurate and timely prognostic information to optimize patient management. In this context, the hematological investigation with a wide spectrum of analyses can be a valid routine support for COVID-19 patient monitoring, who, as demonstrated, share a series of alterations that may be related to the progression and severity of the disease. COVID-19 causes significant changes in the size and rigidity of RBCs; a decrease in the hematocrit level and increased RBCs amplitude referred to as RDW (red blood cell distribution width) has been recorded [107]. RDW is an indicator of the heterogeneity degree of erythrocyte size distribution in the blood, conventionally known as anisocytosis and used as an index of anemia $[108,109]$. A high RDW is considered a negative value for the diagnosis of different pathologies, such as pulmonary disease, liver and kidney failure, and cardiovascular disease [110-113]. In COVID-19, with the aggravation of the disease, the hematocrit and the concentration of $\mathrm{Hb}$ tend to progressively decrease while RDW increases progressively in the opposite direction. It is estimated that the RDW increase raises the chances of incurring the COVID-19 aggravation by about 9 times, and they are 16 times more likely to have severe acute kidney injury [114]. Therefore, RDW can be interpreted as an indicator of both disease severity and kidney damage in patients with SARS-CoV-2. RDW increase is an index of profound deregulation of RBC homeostasis that can result in impaired erythropoiesis and abnormal RBC survival, both caused by several metabolic alterations, including oxidative stress, inflammation, hypertension, dyslipidemia, hemolysis, and impaired erythropoietin function. Many of these metabolic alterations have been found in severe COVID-19. In particular, RBCs abnormalities recorded in COVID-19 patients may have multiple causes, including: alterations in iron homeostasis that could cause impaired erythropoiesis and accelerated release of circulating RBCs; fragmentation of proteins such as $\beta$-spectrin, ankyrin, Band-3 (at the N-terminal level), and lipid metabolism abnormalities, which could contribute to the morphological abnormalities; oxidative stress, which could contribute to altered flexibility and morphology identified in RBCs $[24,44,69,71,73,115]$.

\section{Nutrients and Natural Bioactive Molecules in the Treatment of COVID-19}

Based on the mechanisms of action of the virus against the RBCs, the search for new molecules to counteract the evolution of the infection and contain the damage caused could be directed towards the molecules of natural origin, such as vitamins with antioxidant effect (vitamin C, E, A) or vitamin D which supports the immune system, enhancing the cell response against the inflammatory state caused by viral infection $[116,117]$. In this context, 
a balanced diet providing an adequate intake of carbohydrates, lipids, proteins, vitamins, and minerals (such as selenium zinc, iron, copper, and magnesium) can play a key role in increasing immune defenses. While on the contrary, dietary imbalances, such as a diet low in essential nutrients or too rich in fat, associated with a high risk of obesity, can increase the risk of complications of viral infections. In fact, a higher body mass index was found to be associated with an increased risk of hospitalization and severity of the disease $[118,119]$. In particular, the nanoencapsulation of some polyphenols, including caffeine, quercetin and cocoa flavanols, could provide new ideas to deal with the pandemic [120]. In fact, some flavanols are particularly efficient in counteracting ROS due to the presence of two $\mathrm{OH}$ groups on the $\mathrm{B}$ ring in catechol-type arrangement, supported also by the presence of a hydroxyl group in the 3-position and a double bond between atom carbon C-2 and C-3 of ring $C$ that play a fundamental role in ROS scavenging [121]. Resveratrol, present in red wine and grapes, has been shown to have antioxidant properties and protective activity from $\mathrm{Hb}$ oxidation $[122,123]$. Caffeine, present in coffee and tea, has been shown to inhibit RBC membrane derangement by blocking caspase-3 activation and avoiding the production of carbonate and nitrogen dioxide, particularly harmful to the RBC membrane [124].

\section{Conclusions}

COVID-19 causes several alterations in hematological parameters. These blood abnormalities, if strictly monitored, could become a valid "sentinel" for the control of the evolution of the disease. It has been demonstrated that such blood changes are significantly more common and prominent in patients with severe COVID-19, and they are related to the progression and severity of infection. Thus, blood parameters could become an important potential biomarker for hospitalized patients and could be a valuable contribution to the management of the pandemic. In addition, the strong involvement of oxidative stress in the evolution of viral inflammation in RBCs suggests a possible involvement of nutraceutical and adequate diets as a potential strategy to avoid the cascade of events following SARS-CoV-2 infection, due to their strong involvement in counteracting the damage caused by oxidative stress.

Author Contributions: Conceptualization A.R. and G.L.; writing original draft preparation E.T., A.R., S.F., D.B. and G.L.; review and editing, E.T. and D.B.; supervision E.T. and D.B.; funding acquisition, D.B. All authors have read and agreed to the published version of the manuscript.

Funding: This research received no external funding.

Institutional Review Board Statement: Not applicable.

Informed Consent Statement: Not applicable.

Conflicts of Interest: The authors declare no conflict of interest.

\section{References}

1. Monod, J.; Wyman, J.; Changeaux, J.P. On the nature of the allosteric transition: A plausible model. J. Mol. Biol. 1965, $12,118$. [CrossRef]

2. Abdalla, S.; Farsaci, F.; Tellone, E.; Shirbeeny, W.; Hassan Aziza, M.; Bahabri, F.; Kandil, S. Hemoglobin glycation increases the electric charges on red blood cells: Effects of dielectric polarization. Mater. Chem. Phys. 2022, 276, 125348. [CrossRef]

3. Farsaci, F.; Tellone, E.; Galtieri, A.; Ficarra, S. A thermodynamic characterization of the phenomena evolving in cancer pathology by dielectric relaxation in blood: A new approach by construction of TTM (Thermodynamic Tumor Matrix). J. Mol. Liq. 2020, 316, 113839. [CrossRef]

4. Farsaci, F.; Tellone, E.; Galtieri, A.; Ficarra, S. Phenomenological approach on electromagnetic waves propagation in normal and diabetic blood, influence of the relative macromolecular structures. J. Mol. Liq. 2019, 274, 577-583. [CrossRef]

5. Farsaci, F.; Ficarra, S.; Russo, A.; Galtieri, A.; Tellone, E. Dielectric properties of human diabetic blood: Thermodynamic characterization and new prospective for alternative diagnostic techniques. J. Adv. Dielectr. 2015, 5, 1550021. [CrossRef]

6. Carelli-Alinovi, C.; Ficarra, S.; Russo, A.; Giunta, E.; Barreca, D.; Galtieri, A.; Misiti, F.; Tellone, E. Involvement of acetylcholinesterase and protein kinase $C$ in the protective effect of caffeine against $\beta$-amyloid-induced alterations in red blood cells. Biochimie 2016, 121, 52-59. [CrossRef] 
7. Misiti, F.; Orsini, F.; Clementi, M.E.; Masala, D.; Tellone, E.; Galtieri, A.; Giardina, B. Amyloid peptide inhibits ATP release from human erythrocytes. Biochem. Cell Biol. 2008, 86, 501-508. [CrossRef]

8. Ficarra, S.; Tellone, E.; Giardina, B.; Scatena, R.; Russo, A.; Misiti, F.; Clementi, M.E.; Colucci, D.; Bellocco, E.; Laganà, G.; et al. Derangement of erythrocytic AE1 in beta-thalassemia by caspase 3: Pathogenic mechanisms and implications in red blood cell senescence. J. Memb. Biol. 2009, 228, 43-49. [CrossRef]

9. Corman, V.M.; Muth, D.; Niemeyer, D.; Drosten, C. Hosts and Sources of Endemic Human Coronaviruses. Adv. Virus Res. 2018, 100, 163-188.

10. Paules, C.I.; Marston, H.D.; Fauci, A.S. Coronavirus infections-more than just the common cold. JAMA 2020, 323, 707-708. [CrossRef]

11. Wu, F.; Zhao, S.; Yu, B.; Chen, Y.M.; Wang, W.; Song, Z.G.; Hu, Y.; Tao, Z.W.; Tian, J.H.; Pei, Y.Y.; et al. A new coronavirus associated with human respiratory disease in China. Nature 2020, 579, 265-269. [CrossRef] [PubMed]

12. Gu, J.; Han, B.; Wang, J. COVID-19: Gastrointestinal manifestations and potential fecal-oral transmission. Gastroenterology 2020, 158, 1518-1519. [CrossRef] [PubMed]

13. Hoffmann, M.; Kleine-Weber, H.; Schroeder, S.; Krüger, N.; Herrler, T.; Erichsen, S.; Schiergens, T.S.; Herrler, G.; Wu, N.H.; Nitsche, A.; et al. SARS- CoV-2 cell entry depends on ACE2 and TMPRSS2 and is blocked by a clinically proven protease inhibitor. Cell 2020, 181, 271-280. [CrossRef] [PubMed]

14. Bar-On, Y.M.; Flamholz, A.; Phillips, R.; Milo, R. SARS-CoV-2 (COVID-19) by the numbers. Elife 2020, 9, e57309. [CrossRef]

15. Nishiga, M.; Wang, D.W.; Han, Y.; Lewis, D.B.; Wu, J.C. COVID-19 and cardiovascular disease: From basic mechanisms to clinical perspectives. Nat. Rev. Cardiol. 2020, 17, 543. [CrossRef]

16. Tay, M.Z.; Poh, C.M.; Renia, L.; MacAry, P.A.; Ng, L.F.P. The trinity of COVID-19: Immunity, inflammation and intervention. Nat. Rev. Immunol. 2020, 20, 363-374. [CrossRef]

17. Ragab, D.; Eldin, H.S.; Taeimah, M.; Khattab, R.; Salem, R. The COVID-19 cytokine storm; what we know so far. Front. Immunol. 2020, 11, 1446. [CrossRef]

18. Bikdeli, B.; Madhavan, M.V.; Jimenez, D.; Chuich, T.; Dreyfus, I.; Driggin, E.; Nigoghossian, C.D.; Ageno, W.; Madjid, M.; Guo, Y.; et al. COVID-19 and thrombotic or thromboembolic disease: Implications for prevention, antithrombotic therapy, and follow-up: JACC state of the art review. J. Am. Coll. Cardiol. 2020, 75, 2950-2973. [CrossRef]

19. Yuki, K.; Fujiogi, M.; Koutsogiannaki, S. COVID-19 pathophysiology: A review. Clin. Immunol. 2020, 215, 108427. [CrossRef]

20. Khawaja, U.A.; Shamsoddin, E.; Desideri, L.F.; Tovani-Palone, M.R. Infection of red blood cells by SARS-CoV-2: New evidence [letter]. Einstein 2021, 19, eCE6285. [CrossRef]

21. Cosic, I.; Cosic, D.; Loncarevic, I. RRM prediction of erythrocyte band 3 protein as alternative receptor for SARS-CoV-2 virus. Appl. Sci. 2020, 11, 4053. [CrossRef]

22. Hacking, S.M. Red blood cell exchange for SARS-CoV-2: A Gemini of therapeutic opportunities. Med. Hypotheses 2020, $144,110227$. [CrossRef]

23. Baldwin, M.; Russo, C.; Li, X.; Chishti, A.H. Plasmodium falciparum signal peptide peptidase cleaves malaria heat shock protein 101 (HSP101). Implications for gametocytogenesis. Biochem. Biophys. Res. Commun. 2014, 450, 1427-1432. [CrossRef]

24. Thomas, T.; Stefanoni, D.; Dzieciatkowska, M.; Issaian, A.; Nemkov, T.; Hill, R.C.; Francis, R.O.; Hudson, K.E.; Buehler, P.W.; Zimring, J.C.; et al. Evidence for structural protein damage and membrane lipid remodeling in red blood cells from COVID-19 patients. J. Proteome Res. 2020, 19, 4455-4469. [CrossRef] [PubMed]

25. Beale, D.; Shah, R.; Karpe, A.; Hillyer, K.; McAuley, A.; Au, G.; Marsh, G.; Vasan, S. Metabolic Profiling from an Asymptomatic Ferret Model of SARS-CoV-2 Infection. Metabolites 2021, 11, 327. [CrossRef] [PubMed]

26. Bojkova, D.; Costa, R.; Reus, P.; Bechtel, M.; Jaboreck, M.C.; Olmer, R.; Martin, U.; Ciesek, S.; Michaelis, M.; Cinatl, J., Jr. Targeting the Pentose Phosphate Pathway for SARS-CoV-2 Therapy. Metabolites 2021, 11, 699. [CrossRef] [PubMed]

27. Bartolini, D.; Stabile, A.M.; Bastianelli, S.; Giustarini, D.; Pierucci, S.; Busti, C.; Vacca, C.; Gidari, A.; Francisci, D.; Castronari, R.; et al. SARSCoV2 infection impairs the metabolism and redox function of cellular glutathione. Redox Biol. 2021, $45,102041$. [CrossRef]

28. Kumar, P.; Osahon, O.; Vides, D.B.; Hanania, N.; Minard, C.G.; Sekhar, R.V. Severe Glutathione Deficiency, Oxidative Stress and Oxidant Damage in Adults Hospitalized with COVID-19: Implications for GlyNAC (Glycine and N-Acetylcysteine) Supplementation. Antioxidants 2022, 11, 50. [CrossRef]

29. Muhammad, Y.; Kani, Y.A.; Iliya, S.; Muhammad, J.B.; Binji, A.; Ahmad, A.E.-F.; Kabir, M.B.; Bindawa, K.U.; Ahmed, A.Y. Deficiency of antioxidants and increased oxidative stress in COVID-19 patients: A cross-sectional comparative study in Jigawa, Northwestern Nigeria. SAGE Open Med. 2021, 9, 2050312121991246. [CrossRef]

30. Galtieri, A.; Tellone, E.; Romano, L.; Misiti, F.; Bellocco, E.; Ficarra, S.; Russo, A.; Di Rosa, D.; Castagnola, M.; Giardina, B.; et al. Band-3 protein function in human erythrocytes: Effect of oxygenation-deoxygenation. Biochim. Biophys. Acta (BBA) Biomembr. 2002, 1564, 214-218. [CrossRef]

31. Tellone, E.; Ficarra, S.; Giardina, B.; Scatena, R.; Russo, A.; Clementi, M.E.; Misiti, F.; Bellocco, E.; Galtieri, A. Oxidative effects of gemfibrozil on anion influx and metabolism in normal and beta-thalassaemic erythrocytes, physiological implications. J. Memb. Biol. 2008, 224, 1-8. [CrossRef] [PubMed] 
32. De Rosa, M.C.; Carelli Alinovi, C.; Galtieri, A.; Russo, A.; Giardina, B. Allosteric Properties of Hemoglobin and the Plasma Membrane of the Erythrocyte: New Insights in Gas Transport and Metabolic Modulation. IUBMB Life 2008, 60, 87-93. [CrossRef] [PubMed]

33. Liu, W.; Li, H. COVID-19: Attacks the 1-Beta Chain of Hemoglobin and Captures the Porphyrin to Inhibit Human Heme Metabolism. Biol. Med. Chem. 2020, 17-21.

34. Lechuga, G.C.; Souza-Silva, F.; Sacramento, C.Q.; Trugilho, M.R.; Valente, R.H.; Napoleão-Pêgo, P.; Dias, S.S.; Fintelman-Rodrigues, N.; Temerozo, J.R.; Carels, N.; et al. SARS-CoV-2 Proteins Bind to Hemoglobin and Its Metabolites. Int. J. Mol. Sci. 2021, $22,9035$. [CrossRef]

35. Vzorov, A.N.; Dixon, D.W.; Trommel, J.S.; Marzilli, L.G.; Compans, R.W. Inactivation of human immunodeficiency virus type 1 by porphyrins. Antimicrob. Agents Chemother. 2002, 46, 3917-3925. [CrossRef]

36. Motta, I.; Bou-Fakhredin, R.; Taher, A.T.; Cappellini, M.D. Beta Thalassemia: New Therapeutic Options Beyond Transfusion and Iron Chelation. Drugs 2020, 80, 1053-1063. [CrossRef]

37. Abdelzaher, M.A.; Ibrahim, A.E.; Negm, E.M. Increasing fetal hemoglobin as a possible key for improvement of hypoxia and saving last breath in COVID-19 patient: "Postulating a hypothesis". Egypt. J. Bronch. 2021, 15, 33. [CrossRef]

38. Majeed, A.; Shajar, M.A. Is hemoglobin the missing link in the pathogenesis of COVID-19? Anaesth. Pain Intensive Care 2020, 24, 9-12. [CrossRef]

39. Juan, I.S.; Bruzzone, C.; Bizkarguenaga, M.; Bernardo-Seisdedos, G.; Laín, A.; Gil-Redondo, R.; Diercks, T.; Gil-Martínez, J.; Urquiza, P.; Arana, E.; et al. Abnormal concentration of porphyrins in serum from COVID-19 patients. Br. J. Haematol. 2020, 190, e265. [CrossRef]

40. Shoenfeld, Y. Corona (COVID-19) time musings: Our involvement in COVID-19 pathogenesis, diagnosis, treatment and vaccine planning. Autoimmun. Rev. 2020, 19, 102538. [CrossRef]

41. Cavezzi, A.; Troiani, E.; Corrao, S. COVID-19: Hemoglobin, iron, and hypoxia beyond inflammation. A narrative review. Clin. Pract. 2020, 10, 1271. [PubMed]

42. Da Costa, X.J.; Morrison, L.A.; Knipe, D.M. Comparison of different forms of herpes simplex replication-defective mutant viruses as vaccines in a mouse model of HSV-2 genital infection. Virology 2001, 288, 256-263. [CrossRef] [PubMed]

43. De Domenico, I.; Ward, D.M.; Kaplan, J. Hepcidin regulation: Ironing out the details. J. Clin. Investig. 2007, 117, 1755-1758. [CrossRef] [PubMed]

44. Anai, M.; Akaike, K.; Iwagoe, H.; Akasaka, T.; Higuchi, T.; Miyazaki, A.; Naito, D.; Tajima, Y.; Takahashi, H.; Komatsu, T.; et al. Decrease in hemoglobin level predicts increased risk for severe respiratory failure in COVID-19 patients with pneumonia. Respir. Investig. 2021, 59, 187-193. [CrossRef] [PubMed]

45. Huang, C.; Wang, Y.; Li, X.; Ren, L.; Zhao, J.; Hu, Y.; Zhang, L.; Fan, G.; Xu, J.; Gu, X.; et al. Clinical features of patients infected with 2019 novel coronavirus in Wuhan, China. Lancet 2020, 395, 497-506. [CrossRef]

46. Guan, W.-J.; Ni, Z.-Y.; Hu, Y.; Liang, W.-H.; Ou, C.-Q.; He, J.-X.; Liu, L.; Shan, H.; Lei, C.-L.; Hui, D.S. Clinical characteristics of coronavirus disease 2019 in China. N. Engl. J. Med. 2020, 382, 1708-1720. [CrossRef]

47. Tao, Z.; Liu, M.; Wu, J.; Xu, J.; Chen, W.; Yang, Z.; Xu, X.; Liu, L.; Chen, R.; Xie, J. Anaemia is associated with severe illness in COVID-19: A retrospective cohort study. J. Med. Virol. 2020, 19, 1478-1488. [CrossRef]

48. Young, B.; Ong, S.; Kalimuddin, S.; Low, J.; Tan, S.; Loh, J.; Ng, O.; Marimuthu, K.; Ang, L.; Mak, T.; et al. Epidemiologic Features and Clinical Course of Patients Infected With SARS-CoV-2 in Singapore. JAMA 2020, 323, 1488-1494. [CrossRef]

49. De Martino, A.W.; Rose, J.J.; Amdahl, M.B.; Dent, M.R.; Shah, F.A.; Bain, W.; McVerry, B.J.; Kitsios, G.D.; Tejero, J.; Gladwin, M.T. No evidence of hemoglobin damage by SARS-CoV-2 infection. Haematologica 2020, 105, 2769-2773. [CrossRef]

50. Laredo, M.; Curis, E.; Masson-Fron, E.; Voicu, S.; Mégarbane, B. Does COVID-19 alter the oxyhemoglobin dissociation curve? An observational cohort study using a mixed-effect modelling. Clin. Chem. Lab. Med. (CCLM) 2021, 59, e416-e419. [CrossRef]

51. Gille, T.; Sesé, L.; Aubourg, E.; Fabre, E.E.; Cymbalista, F.; Ratnam, K.C.; Valeyre, D.; Nunes, H.; Richalet, J.P.; Planès, C.; et al. The affinity of hemoglobin for oxygen is not altered during COVID-19. Front. Physiol. 2021, 12, 578708. [CrossRef] [PubMed]

52. Wang, D.; Hu, B.; Hu, C.; Zhu, F.; Liu, X.; Zhang, J.; Wang, B.; Xiang, H.; Cheng, Z.; Xiong, Y.; et al. Clinical characteristics of 138 hospitalized patients with 2019 novel coronavirus-infected pneumonia in Wuhan, China. JAMA 2020, 323, 1061-1069. [CrossRef] [PubMed]

53. Zhou, Z.; Qiu, Y.; Ge, X. The taxonomy, host range and pathogenicity of coronaviruses and other viruses in the Nidovirales order. Anim. Dis. 2021, 1, 5. [CrossRef] [PubMed]

54. Scholkmann, F.; Restin, T.; Ferrari, M.; Quaresima, V. The Role of Methemoglobin and Carboxyhemoglobin in COVID-19: A Review. J. Clin. Med. 2021, 10, 50. [CrossRef]

55. Naymagon, L.; Berwick, S.; Kessler, A.; Lancman, G.; Gidwani, U.; Troy, K. The emergence of methemoglobinemia amidst the COVID-19 pandemic. Am. J. Hematol. 2020, 95, E196-E197. [CrossRef] [PubMed]

56. Palmer, K.; Dick, J.; French, W.; Floro, L.; Ford, M. Methemoglobinemia in patient with G6PD deficiency and SARS-CoV-2 Infection. Emerg. Infect. Dis. 2020, 26, 2279-2281. [CrossRef]

57. Hare, G.M.T.; Tsui, A.K.Y.; Crawford, J.H.; Patel, R.P. Is methemoglobin an inert bystander, biomarker or a mediator of oxidative stress-The example of anemia? Redox Biol. 2013, 1, 65-69. [CrossRef]

58. Jurado, R.L. Iron, infections, and anemia of inflammation. Clin. Infect. Dis. 1997, 25, 888-895. [CrossRef]

59. Ganz, T.; Longo, D.L. Anemia of Inflammation. N. Engl. J. Med. 2019, 381, 1148-1157. [CrossRef] 
60. Mortaz, E.; Malkmohammad, M.; Jamaati, H.; Naghan, P.A.; Hashemian, S.M.; Tabarsi, P.; Varahram, M.; Zaheri, H.; Chousein, E.G.; Folkerts, G.; et al. Silent hypoxia: Higher NO in red blood cells of COVID-19 patients. BMC Pulm Med. $2020,20,269$.

61. Lazarian, G.; Quinquenel, A.; Bellal, M.; Siavellis, J.; Jacquy, C.; Re, D.; Merabet, F.; Mekinian, A.; Braun, T.; Damaj, G.; et al Autoimmune haemolytic anaemia associated with COVID-19 infection. Br. J. Haematol. 2020, 190, 29-31. [CrossRef] [PubMed]

62. Taneri, P.E.; Gómez-Ochoa, S.A.; Llanaj, E.; Raguindin, P.F.; Rojas, L.Z.; Roa-Díaz, Z.M.; Salvador, D.; Groothof, D.; Minder, B.; Kopp-Heim, D.; et al. Anemia and iron metabolism in COVID-19: A systematic review and meta-analysis. Eur. J. Epidemiol. 2020, 35, 763-773. [CrossRef] [PubMed]

63. Lanser, L.; Burkert, F.R.; Bellmann-Weiler, R.; Schroll, A.; Wildner, S.; Fritsche, G.; Weiss, G. Dynamics in Anemia Development and Dysregulation of Iron Homeostasis in Hospitalized Patients with COVID-19. Metabolites 2021, 11, 653. [CrossRef]

64. Sonnweber, T.; Boehm, A.; Sahanic, S.; Pizzini, A.; Aichner, M.; Sonnweber, B.; Kurz, K.; Koppelstätter, S.; Haschka, D.; Petzer, V.; et al. Persisting alterations of iron homeostasis in COVID-19 are associated with non-resolving lung pathologies and poor patients' performance: A prospective observational cohort study. Respir. Res. 2020, 21, 276. [CrossRef] [PubMed]

65. Zhao, K.; Huang, J.; Dai, D.; Feng, Y.; Liu, L.; Nie, S. Serum iron level as a potential predictor of coronavirus disease 2019 severity and mortality: A retrospective study. Open Forum Infect. Dis. 2020, 7, 1-8. [CrossRef]

66. Bagnato, G.; Rosa, D.L.; Ioppolo, C.; Gaetano, A.D.; Chiappalone, M.; Zirilli, N.; Viapiana, V.; Tringali, M.C.; Tomeo, S.; Aragona, C.O.; et al. The COVID-19 Assessment for Survival at Admission (CASA) Index: A 12 Months Observational Study. Front. Med. 2021, 8, 719976. [CrossRef]

67. Schmidt, S.M. The role of iron in viral infections. Front. Biosci. Landmark. 2020, 25, 893-911. [CrossRef]

68. Rabaan, A.A.; Al-Ahmed, S.H.; Muhammad, J.; Khan, A.; Sule, A.A.; Tirupathi, R.; Mutair, A.A.; Alhumaid, S.; Al-Omari, A.; Dhawan, M.; et al. Role of Inflammatory Cytokines in COVID-19 Patients: A Review on Molecular Mechanisms, Immune Functions, Immunopathology and Immunomodulatory Drugs to Counter Cytokine Storm. Vaccines 2021, 9, 436. [CrossRef]

69. Camaschella, C.; Nai, A.; Silvestri, L. Iron metabolism and iron disorders revisited in the hepcidin era. Haematologica 2020, 105, 260-272. [CrossRef]

70. Ehsani, S. COVID-19 and iron dysregulation: Distant sequence similarity between hepcidin and the novel coronavirus spike glycoprotein. Biol. Direct. 2020, 15, 19. [CrossRef]

71. Bellmann-Weiler, R.; Lanser, L.; Barket, R.; Rangger, L.; Schapfl, A.; Schaber, M.; Fritsche, G.; Wöll, E.; Weiss, G. Prevalence and predictive value of anemia and dysregulated iron homeostasis in patients with COVID-19 infection. J. Clin. Med. 2020, 9, 2429. [CrossRef] [PubMed]

72. Mancilha, E.M.B.; de Oliveira, J.S.R. SARS-CoV-2 association with hemoglobin and iron metabolism. Rev. Assoc. Med. Bras. 2021, 67, 1349-1352. [CrossRef] [PubMed]

73. Shah, A.; Frost, J.N.; Aaron, L.; Donovan, K.; Drakesmith, H. Systemic hypoferremia and severity of hypoxemic respiratory failure in COVID-19. Crit. Care 2020, 24, 320. [CrossRef] [PubMed]

74. Yang, Y.; Bazhin, A.V.; Werner, J.; Karakhanova, S. Reactive oxygen species in the immune system. Int. Rev. Immunol. 2013, 32, 249-270. [CrossRef]

75. Violi, F.; Oliva, A.; Cangemi, R.; Ceccarelli, G.; Pignatelli, P.; Carnevale, R.; Cammisotto, V.; Lichtner, M.; Alessandri, F.; De Angelis, M.; et al. Nox2 activation in COVID-19. Redox Biol. 2020, 36, 101655. [CrossRef] [PubMed]

76. Damiano, S.; Sozio, C.; La Rosa, G.; Santillo, M. NOX-Dependent Signaling Dysregulation in Severe COVID-19: Clues to Effective Treatments. Front. Cell. Infect. Microbiol. 2020, 10, 608435. [CrossRef]

77. Klok, F.A.; Kruip, M.J.H.A.; van der Meer, N.J.M.; Arbous, M.S.; Gommers, D.A.M.P.J.; Kant, K.M.; Kaptein, F.H.J.; van Paassen, J.; Stals, M.A.M.; Huisman, M.V.; et al. Incidence of thrombotic complications in critically ill ICU patients with COVID-19. Thromb Res. 2020, 191, 145-147. [CrossRef]

78. Varga, Z.; Flammer, A.J.; Steiger, P.; Haberecker, M.; Andermatt, R.; Zinkernagel, A.S.; Mehra, M.R.; Schuepbach, R.A.; Ruschitzka, F.; Moch, H.; et al. Endothelial cell infection and endotheliitis in COVID-19. Lancet 2020, 395, 1417-1418. [CrossRef]

79. Delgado-Roche, L.; Mesta, F. Oxidative Stress as Key Player in Severe Acute Respiratory Syndrome Coronavirus (SARS-CoV) Infection. Arch. Med. Res. 2020, 51, 384-387. [CrossRef]

80. Fratta Pasini, A.M.; Stranieri, C.; Girelli, D.; Busti, F.; Cominacini, L. Is Ferroptosis a Key Component of the Process Leading to Multiorgan Damage in COVID-19? Antioxidants 2021, 10, 1677. [CrossRef]

81. Khomich, O.A.; Kochetkov, S.N.; Bartosch, B.; Ivanov, A.V. Redox Biology of Respiratory Viral Infections. Viruses 2018, 10, 392. [CrossRef] [PubMed]

82. Amatore, D.; Sgarbanti, R.; Aquilano, K.; Baldelli, S.; Limongi, D.; Civitelli, L.; Nencioni, L.; Garaci, E.; Ciriolo, M.R.; Palamara, A.T. Influenza virus replication in lung epithelial cells depends on redox-sensitive pathways activated by NOX4-derived ROS. Cell Microbiol. 2015, 17, 131-145. [CrossRef] [PubMed]

83. Abouhashem, A.S.; Singh, K.; Azzazy, H.M.E.; Sen, C.K. Is Low Alveolar Type II Cell SOD3 in the Lungs of Elderly Linked to the Observed Severity of COVID-19? Antioxid Redox Signal. 2020, 33, 59-65. [CrossRef] [PubMed]

84. Suhail, S.; Zajac, J.; Fossum, C.; Lowater, H.; McCracken, C.; Severson, N.; Laatsch, B.; Narkiewicz-Jodko, A.; Johnson, B.; Liebau, J.; et al. Role of oxidative stress on SARS-CoV (SARS) and SARS-CoV-2 (COVID-19) infection: A review. Protein J. 2020, 39, 644-656. [CrossRef]

85. Polonikov, A. Endogenous deficiency of glutathione as the most likely cause of serious manifestations and death in COVID-19 patients. ACS Infect. Dis. 2020, 6, 1558-1562. [CrossRef] 
86. Horowitz, R.I.; Freeman, P.R.; Bruzzese, J. Efficacy of glutathione therapy in relieving dyspnea associated with COVID-19 pneumonia: A report of two cases. Respir. Med. Case Rep. 2020, 30, 101063. [CrossRef]

87. Doğan, S.; Bal, T.; Çabalak, M.; Dikmen, N.; Yaqoobi, H.; Ozcan, O. Oxidative stress index can be a new marker related to disease severity in COVID-19. Turk. J. Biochem. 2021, 46, 349-357. [CrossRef]

88. Renoux, C.; Fort, R.; Nader, E.; Boisson, C.; Joly, P.; Stauffer, E.; Robert, M.; Girard, S.; Cibiel, A.; Gauthier, A.; et al. Impact of COVID-19 on red blood cell rheology. Br. J. Haematol. 2021, 192, e108-e111. [CrossRef]

89. Ney, P.A.; Christopher, M.M.; Hebbel, R.P. Synergistic effects of oxidation and deformation on erythrocyte monovalent cation leak. Blood 1990, 75, 1192-1198. [CrossRef]

90. Wang, Q.; Zennadi, R. Oxidative Stress and Thrombosis during Aging: The Roles of Oxidative Stress in RBCs in Venous Thrombosis, Int. J. Mol. Sci. 2020, 21, 4259. [CrossRef]

91. Griffith, O.W.; Stuehr, D.J. Nitricoxide synthases: Properties and catalytic mechanism. Annu. Rev. Physiol. 1995, 57, 707-734. [CrossRef] [PubMed]

92. Wennmalm, A.; Benthin, G.; Petersson, A.S. Dependence of the metabolism of nitric oxide (NO) in healthy human whole blood on the oxygenation of its red cell haemoglobin. Br. J. Pharmacol. 1992, 106, 507-508. [CrossRef] [PubMed]

93. Ozdemir, B.; Yazici, A. Could the decrease in the endothelial nitric oxide (NO) production and NO bioavailability be the crucial cause of COVID-19 related deaths? Med. Hypotheses 2020, 144, 109970. [CrossRef] [PubMed]

94. Fang, W.; Jiang, J.; Su, L.; Shu, T.; Liu, H.; Lai, S.; Ghiladi, R.A.; Wang, J. The role of NO in COVID-19 and potential therapeutic strategies. Free Radic Biol. Med. 2021, 163, 153-162. [CrossRef]

95. Wilkerson, R.G.; Adler, J.D.; Shah, N.G.; Brown, R. Silent hypoxia: A harbinger of clinical deterioration in patients with COVID-19. Am. J. Emerg. Med. 2020, 38, 2243.e5-2243.e6. [CrossRef]

96. Tobin, M.J.; Laghi, F.; Jubran, A. Why COVID-19 Silent Hypoxemia Is Baffling to Physicians. Am. J. Respir. Crit. Care Med. 2020, 202, 356-360. [CrossRef]

97. Connors, J.M.; Levy, J.H. COVID-19 and its implications for thrombosis and anticoagulation. Blood 2020, 135, 2033-2040. [CrossRef]

98. Miesbach, W.; Makris, M. COVID-19: Coagulopathy, Risk of Thrombosis, and the Rationale for Anticoagulation. Clin. Appl Thromb. Hemost. 2020, 26, 1076029620938149. [CrossRef]

99. Teixeira, C.F.S.; Soares, C.M.; Souza, E.A.; Lisboa, E.S.; Pinto, I.C.M.; Andrade, L.R.; Espiridião, M.A. The health of healthcare professionals coping with the COVID-19 pandemic. Cien Saude Colet. 2020, 25, 3465-3474. [CrossRef]

100. Bohlen, H.G. Nitric oxide and the cardiovascular system. Compr. Physiol. 2015, 5, 808-823.

101. Huang, C.; Huang, L.; Wang, Y.; Li, X.; Ren, L.; Gu, X.; Kang, L.; Guo, L.; Liu, M.; Zhou, X.; et al. 6-month consequences of COVID-19 in patients discharged from hospital: A cohort study. Lancet 2021, 397, 220-232. [CrossRef]

102. Carfi, A.; Bernabei, R.; Landi, F. Persistent symptoms in patients after acute COVID-19. JAMA 2020, 324, 603-605. [CrossRef]

103. Marshall, M. The lasting misery of coronavirus long-haulers. Nature 2020, 585, 339-341. [CrossRef] [PubMed]

104. Pasini, E.; Corsetti, G.; Romano, C.; Scarabelli, T.M.; Chen-Scarabelli, C.; Saravolatz, L.; Dioguardi, F.S. Serum Metabolic Profile in Patients with Long-COVID (PASC) Syndrome: Clinical Implications. Front. Med. 2021, 22, 714426. [CrossRef] [PubMed]

105. Kubankova, M.; Hohberger, B.; Hoffmanns, J.; Furst, J.; Herrmann, M.; Guck, J.; Krater, M. Physical phenotype of blood cells is altered in COVID-19. Biophys. J. 2021, 120, 2838-2847. [CrossRef]

106. Misiti, F. SARS-CoV-2 infection and red blood cells: Implications for long term symptoms during exercise. Sports Med. Health Sci. 2021, 3, 181-182. [CrossRef]

107. Dhinata, K. Common Change of Complete Blood Count Parameters in COVID-19: A Literature Review. J. Med. Health 2021, 3 , 198-207. [CrossRef]

108. Salvagno, G.L.; Sanchis-Gomar, F.; Picanza, A.; Lippi, G. Red blood cell distribution width: A simple parameter with multiple clinical applications. Crit. Rev. Clin. Lab. Sci. 2015, 52, 86-105. [CrossRef] [PubMed]

109. Lippi, G.; Mattiuzzi, C.; Cervellin, G. Learning more and spending less with neglected laboratory parameters: The paradigmatic case of red blood cell distribution width. Acta Biomed. 2016, 87, 323-328.

110. Forhecz, Z.; Gombos, T.; Borgulya, G.; Pozsonyi, Z.; Prohaszka, Z.; Janoskuti, L. Red cell distribution width in heart failure: Prediction of clinical events and relationship with markers of ineffective erythropoiesis, inflammation, renal function, and nutritional state. Am. Heart J. 2009, 158, 659-666. [CrossRef]

111. Oh, H.J.; Park, J.T.; Kim, J.K.; Yoo, D.E.; Kim, S.J.; Han, S.H.; Kang, S.W.; Choi, K.H.; Yoo, T.H. Red blood cell distribution width is an independent predictor of mortality in acute kidney injury patients treated with continuous renal replacement therapy. Nephrol. Dial. Transplant. 2012, 27, 589-594. [CrossRef] [PubMed]

112. Seyhan, E.C.; Ozgul, M.A.; Tutar, N.; Omur, I.; Uysal, A.; Altin, S. Red blood cell distribution and survival in patients with chronic obstructive pulmonary disease. J. Chronic Obstr. Pulm. Disease 2013, 10, 416-424. [CrossRef] [PubMed]

113. Fava, C.; Cattazzo, F.; Hu, Z.D.; Lippi, G.; Montagnana, M. The role of red blood cell distribution width (RDW) in cardiovascular risk assessment: Useful or hype? Ann. Transl. Med. 2019, 7, 581. [CrossRef]

114. Henry, B.M.l.; Benoit, J.L.; Benoit, S.; Pulvino, C.; Berger, B.A.; Santos de Olivera, M.H.; Crutchfield, C.A.; Lippi, G. Red Blood Cell Distribution Width (RDW) Predicts COVID-19 Severity: A Prospective, Observational Study from the Cincinnati SARS-CoV-2 Emergency Department Cohort. Diagnostics 2020, 10, 618. [CrossRef] [PubMed] 
115. Yan, B.; Chu, H.; Yang, D.; Sze, K.H.; Lai, P.M.; Yuan, S.; Shuai, H.; Wang, Y.; Kao, R.Y.; Chan, J.F.; et al. Characterization of the Lipidomic Profile of Human Coronavirus-Infected Cells: Implications for Lipid Metabolism Remodeling upon Coronavirus Replication. Viruses 2019, 11, 73. [CrossRef]

116. Adams, K.K.; Baker, W.L.; Sobieraj, D.M. Myth Busters: Dietary Supplements andn COVID-19. Ann. Pharm. 2020, 54, 820-826. [CrossRef] [PubMed]

117. Quiles, J.L.; Rivas-García, L.; Varela-López, A.; Llopis, J.; Battino, M.; Sánchez-González, C. Do nutrients and other bioactive molecules from foods have anything to say in the treatment against COVID-19? Envion. Res. 2020, 191, 110053. [CrossRef]

118. Bagnato, C.; Perfetto, C.; Labanca, F.; Caregaro Negrin, L. The Mediterranean Diet: Healthy and Sustainable Dietary Pattern in the Time of SARS-CoV-2. Med. J. Nutr. Met. 2021, 14, 365-381. [CrossRef]

119. Cena, H.; Maffoni, S.; Braschi, V.; Brazzo, S.; Pallavicini, C.; Vietti, I.; Portale, S.; Corra, E. Position Paper of the Italian Association of Medical Specialists in Dietetics and Clinical Nutrition (ANSISA) on Nutritional Management of Patients with COVID-19 Disease. Med. J. Nutr. Met. 2020, 13, 113-117. [CrossRef]

120. Noor, N.; Gani, A.; Gani, A.; Shah, A.; Ashraf, Z.U. Exploitation of polyphenols and proteins using nanoencapsulation for anti-viral and brain boosting properties-Evoking a synergistic strategy to combat COVID-19 pandemic. Int. J. Biol. Macromol. 2021, 180, 375-384. [CrossRef]

121. Gervasi, T.; Calderaro, A.; Barreca, D.; Tellone, E.; Trombetta, D.; Ficarra, S.; Smeriglio, A.; Mandalari, G.; Gattuso, G. Biotechnological Applications and Health-Promoting Properties of Flavonols: An Updated View. Int. J. Mol. Sci. 2022, 23, 1710. [CrossRef] [PubMed]

122. Ficarra, S.; Tellone, E.; Pirolli, D.; Russo, A.; Barreca, D.; Galtieri, A.; Giardina, B.; Gavezzotti, P.; Riva, S.; De Rosa, M.C. Insights into the properties of the two enantiomers of trans- $\delta$-viniferin, a resveratrol derivative: Antioxidant activity, biochemical and molecular modeling studies of its interactions with hemoglobin. Mol. Bio Syst. 2016, 12, 1276-1286. [CrossRef] [PubMed]

123. Tellone, E.; De Rosa, M.C.; Pirolli, D.; Russo, A.; Giardina, B.; Galtieri, A.; Ficarra, S. Molecular interactions of hemoglobin with resveratrol: Potential protective antioxidant role and metabolic adaptations of the erythrocyte. Biol. Chem. 2014, 395, 347-354. [CrossRef] [PubMed]

124. Tellone, E.; Ficarra, S.; Russo, A.; Bellocco, E.; Barreca, D.; Laganà, G.; Leuzzi, U.; Pirolli, D.; De Rosa, M.C.; Giardina, B.; et al. Caffeine inhibits erythrocyte membrane derangement by antioxidant activity and by blocking caspase 3 activation. Biochimie 2012, 94, 393-402. [CrossRef] [PubMed] 